\title{
Abundance patterns of subtidal benthic invertebrates and fishes at the Kermadec Islands
}

\author{
Russell G. Cole ${ }^{1}$, Robert G. Creese ${ }^{1}$, Roger V. Grace ${ }^{2}$, Paul Irving ${ }^{2}$, Bill R. Jackson ${ }^{1}$ \\ ${ }^{1}$ Leigh Marine Laboratory \& Zoology Department, University of Auckland, Private Bag 92019, Auckland, New Zealand \\ ${ }^{2}$ Department of Conservation, Auckland Regional Office, Private Bag 68908, Newton, Auckland, New Zealand
}

\begin{abstract}
Vertical distributions of benthic fauna and fish are described for a number of sites at the subtropical Kermadec Islands $\left(30^{\circ} \mathrm{S}, 178^{\circ} \mathrm{W}\right)$. Six sites throughout the entire group were quantitatively sampled; samples consisted of timed counts (for benthic and pelagic fish) or quadrat counts (for mobile benthic invertebrates) at various water depths. Ten species of mobile benthic invertebrates were identified in quadrats. The endemic limpet Patella kermadecensis was confined to shallow water at all sites. The echinoid Heliocidaris tuberculata was also abundant in depths less than $9 \mathrm{~m}$, while Centrostephanus rodgersii was most abundant at greater depths. Twelve species of fish were identified in pelagic counts. There was some depth stratification in the abundances of pelagic fish: Labracoglossa nitida, Bathystethus cultratus, and Kyphosus bigibbus were all more abundant in counts shallower than $10 \mathrm{~m}$, while Chromis dispilus was more abundant at greater depths. Thirty-four species of fish were identified in benthic counts. Most showed no consistent depth-related trends, but Aplodactylus etheridgii and Stegastes fasciolatus were more abundant in shallow water, while Chrysiptera rapanui was most abundant in the deep stratum. Our data support previously described patterns of vertical distribution of the marine fauna at the Kermadec Islands, and suggest that the abundances of herbivores are insufficient to account for the lack of macroalgae. Further, we suggest that more detailed studies in subtropical regions may provide a better understanding of the fundamental differences between temperate and tropical reefs.
\end{abstract}

\section{INTRODUCTION}

There are very apparent differences between temperate and tropical shallow reefs. Macroalgal biomass is lower at low latitudes; in temperate waters laminarian and fucoid macroalgae frequently form dense stands (Schiel \& Foster 1986), whereas tropical reefs generally are characterised by inconspicuous calcified algae (Gaines \& Lubchenco 1982). Echinoids are a conspicuous element of both temperate (Lawrence 1975) and tropical (Birkeland 1989) reefs, but members of the genus Diadema tend to dominate the latter. Many families of fishes which are speciose and abundant on tropical reefs do not occur on temperate reefs (Choat 1982).

These latitudinal patterns may be linked causally; it has been argued that grazing is more intense in the tropics, and that this may account for the absence, or reduced abundance, of macroalgae there (Gaines \& Lubchenco 1982). In temperate waters, grazing by a variety of regular echinoids may remove stands of macrophytes and produce areas dominated by coralline algae (Lawrence 1975, Ayling 1981. Fletcher 1987. Harrold \& Pearse 1987. Underwood et al. 1991). The dominant grazers in tropical waters are thought to be fishes, particularly acanthurids and scarids, and echinoid grazing is thought to be important only in areas where the impact of these fishes has been reduced (Jones \& Andrew 1990). In reviewing the impact of fish feeding, Choat (1982) pointed out that herbivorous fishes may be abundant in temperate waters. Recently, however, Horn (1989) concluded that there were insufficient data to allow an adequate comparison of the abundances of herbivorous fishes in temperate and tropical waters.

Steneck (1988) reviewed patterns of herbivory with depth on coral reefs and concluded that grazing reached a peak between 1 and $5 \mathrm{~m}$. Horn (1989) also concluded that plant-eating fishes were most abundant at shallow depths on tropical reefs, and noted 
that scarids typically fed at greater depths than acanthurids. In northern New Zealand, echinoid grazing is most intense at depths between 5 and $10 \mathrm{~m}$ (Choat \& Schiel 1982), and herbivorous fish are most abundant in macroalgal stands from 2 to $8 \mathrm{~m}$ depth (Meekan 1986). In temperate regions, the vertical distribution of fishes may be linked to biogenic habitats (Choat \& Ayling 1987), so that the greatest abundances of piscine herbivores and algal-picking carnivores occur at depths where macroalgae are abundant, and benthic carnivores are most abundant in coralline-dominated areas. In tropical regions, macroalgae are frequently restricted to shallow depths where wave action reduces herbivore activity (Gaines \& Lubchenco 1982). The general implication from these studies is that, in temperate waters, the vertical distribution of the piscine herbivores is determined by macroaigal stands, whereas in the tropics the vertical distribution of macroalgae is strongly influenced by the activity of grazing fishes (Jones \& Andrew 1990). Echinoids, however, may control the distribution of macroalgae in both temperate and tropical systems (Schiel \& Foster 1986, Birkeland 1989)

Subtropical regions may provide the key to understanding the fundamental biotic differences between temperate and tropical reefs. The subtropics (also referred to as 'warm temperate waters'; e.g Knox 1963) lie intermediate between temperate and tropical regions. While the tropics of Cancer and Capricorn are obvious equatorial boundaries, polar limits are poorly defined. Temperate regions are usually considered to lie at latitudes greater than $40^{\circ}$ (Meteorological Office 1963), but studies at lower latitudes are included in some reviews of temperate community organisation (e.g. Choat 1982, Schiel \& Foster 1986). For the purposes of our discussion, we consider latitudes of 23.5 to $32.5^{\circ}$ to be subtropical.

Although subtropical areas may offer important insights into latitudinal variation in the interrelationships between macroalgal abundance and marine faunas, descriptions of the flora and fauna of subtropical areas are few. In Western Australia, Hatcher \& Rimmer (1985) describe patterns of abundance of algae and herbivores at the Houtman Abrolhos (28 to $29^{\circ} \mathrm{S}$, $114^{\circ}$ E), while Gordon (1986) describes shallow subtidal communities near Shoalwater Bay $\left(32.3^{\circ} \mathrm{S}\right.$, $\left.115.7^{\circ} \mathrm{E}\right)$. Veron et al. (1974) noted that at the Solitary Islands $\left(30^{\circ} \mathrm{S}, 153^{\circ} \mathrm{E}\right)$ off the eastern Australian coast, corals occurred intermixed with algae. Coles (1988) and Crossland (1988) review a number of other studies from high latitude coral reefs, and Crossland concludes that these reefs have lower faunal richness, lower coral cover, and more calcareous fleshy macroalgae than tropical reefs.
In the southwestern Pacific Ocean there are 3 isolated subtropical islands which offer opportunities for further studies: Lord Howe Island $\left(31.5^{\circ} \mathrm{S}, 159^{\circ} \mathrm{E}\right)$, Norfolk island $\left(29^{\circ} \mathrm{S}, 168^{\circ} \mathrm{E}\right)$, and the Kermadec Islands $\left(30^{\circ} \mathrm{S}, 178^{\circ} \mathrm{W}\right)$. Species lists for some of the marine flora and fauna of these islands are available (Oliver 1910, 1915, Waite 1910, 1912, 1916, McKnight 1968, Allen et al. 1976, Nelson \& Adams 1984, Hermes 1986. Francis 1991), but there is published information on the abundances of grazers only for the Kermadecs (Schiel et al. 1986; Francis et al. 1987). Information on the vertical distribution of organisms is limited to a single site at the Kermadecs (Schiel et al. 1986).

These studies describe a unique grazing fauna in which species that are characteristic of tropical systems (scarid and acanthurid fishes; echinoids of the genus Diadema) are either absent or extremely rare. Stands of large macroalgae are apparently absent (Schiel et al. 1986), although isolated clumps of Sargassum sp. have been observed from time to time (e.g. at Havre Rock; M. P. Francis, pers. comm.). The fish and benthic invertebrate faunas contain both temperate and subtropical elements, some of which are found in northern New Zealand (Choat et al. 1988).

Our study was concentrated at the Kermadecs, and sought to quantify the patterns of vertical distribution of these organisms in the absence of algal stands, and hence determine the generality of the patterns described by Schiel et al. (1986). In order to do this, we sampled single sites on islands throughout the whole group. Ideally, multiple sites in the order of hundreds of metres apart would have been sampled at each of the more widespread islands. Time and weather limitations did not permit us to do this, and an overall coverage of the group was considered of more use than detailed descriptions of patterns within a given locality (island). Additional preliminary information was also obtained from Norfolk Island, for which there is no published, quantitative data. We compare the overall patterns we observed to those reported from northern New Zealand (Choat \& Schiel 1982) and other subtropical areas (e.g. Allen et al. 1976. Hatcher \& Rimmer 1985). Further, we speculate as to whether herbivores are sufficiently plentiful to account for the observed lack of abundant laminarian and fucalean macroalgae at these subtropical localities.

\section{METHODS}

All sampling at the Kermadecs was done in September 1988 while SCUBA diving. Mobile benthic invertebrates and pelagic fish were sampled at 4 (nonconcurrent) sites, and benthic fish at 6 sites. Sites were deliberately spread throughout the Kermadec group 
Fig. 1. Kermadec Islands showing (a) the 3 island clusters that make up the group and (b) an enlargement of the Herald Islets off Raoul Island. Sampling sites are indicated by arrows
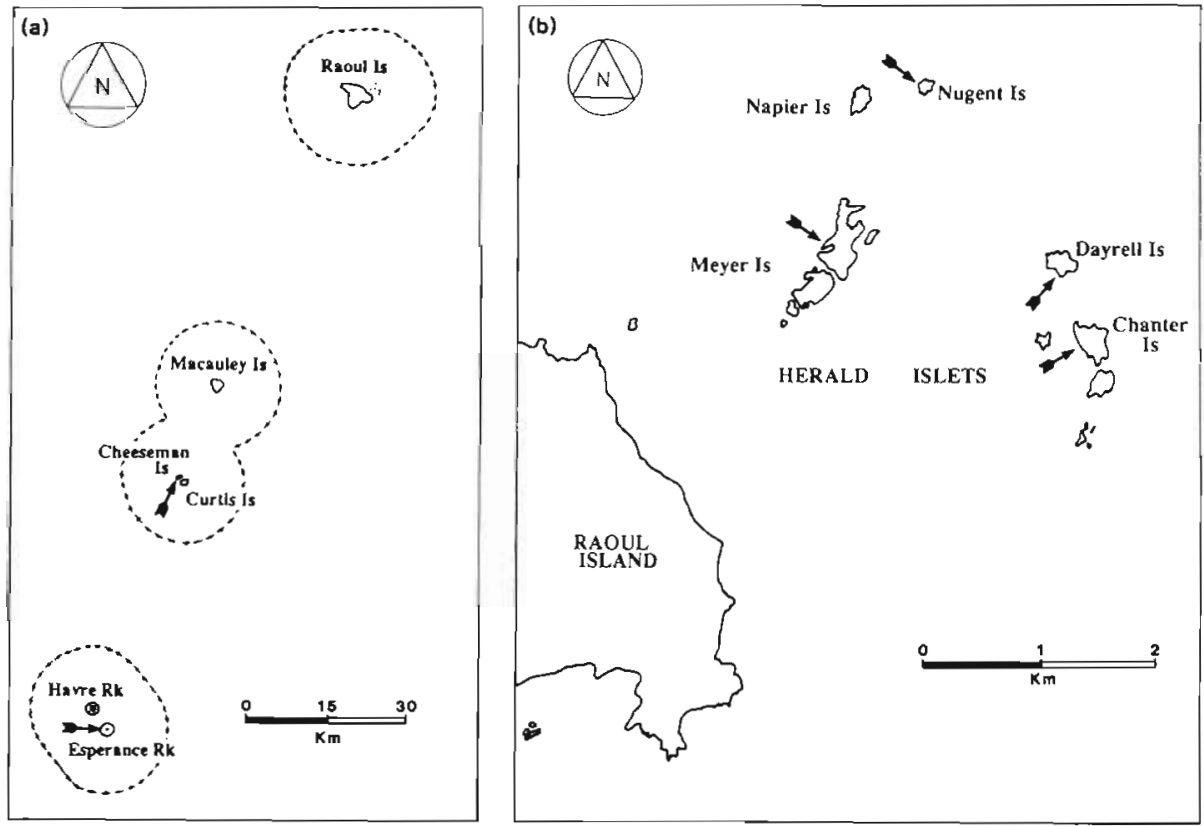

(Fig. 1), but were haphazardly chosen at any particular island. The choice on any particular day depended on the prevailing weather conditions on that day (these can change dramatically from one day to the next), but every effort was made to avoid a biassed selection. One diver carried out all sampling for each faunal group. In addition, we were able to sample 2 sites at Norfolk Island in November 1989 for benthic invertebrates.

Mobile benthic invertebrates were sampled by counting all large invertebrates in three $1 \mathrm{~m}^{2}$ quadrats on the substratum. The quadrats were spaced $1 \mathrm{~m}$ apart horizontally along the depth contour being sampled, to avoid difficulties with maintaining depth strata on steep rock faces. This was done at depth intervals of $3 \mathrm{~m}$, from 3 to $21 \mathrm{~m}$ except at Chanter Island where the $21 \mathrm{~m}$ depth stratum was not sampled.

Fish were sampled in 3 depth strata: shallow $(0-10 \mathrm{~m})$, mid $(10-18 \mathrm{~m})$, and deep (>18 m), using 3 replicate $3 \mathrm{~min}$ timed counts. This method was chosen because it is widely recognised to be the most time efficient means of collecting quantitative data on broad-scale surveys (e.g. Kingsford 1989). The diver counted all fish seen within $2.5 \mathrm{~m}$ of his path; for counts of benthic fish this was in the horizontal plane only, while for counts of pelagic fish the diver also counted fish $2.5 \mathrm{~m}$ above and below his path. Counts of benthic fish were not made in the deep stratum at the Meyer Island site, and pelagic fish were not counted at mid depths at Dayrell Island. Underwater visibility was greater than $10 \mathrm{~m}$ at all times during sampling.

\section{RESULTS}

\section{Species occurrence at the Kermadec Islands}

Ten species of benthic invertebrates ( 2 molluscs and 8 echinoderms) were found during quadrat sampling (Table 1), with approximately 2 species being encountered in each quadrat. Thirty-five species of fish were counted in benthic transects (Table 2) and 9 in mid-

Table 1 Benthic invertebrates found in quadrats at the Kermadec Islands, total no. of individuals counted, and no. of sites (out of 4 ) at which they were encountered

\begin{tabular}{|c|c|c|}
\hline Species & Total no. & No. of sites \\
\hline \multicolumn{3}{|l|}{ Mollusca } \\
\hline Patella kermadecensis Pilsbry & 180 & 3 \\
\hline Tectus royanus (Iredale) & 17 & 3 \\
\hline \multicolumn{3}{|l|}{ Echinoidea } \\
\hline $\begin{array}{l}\text { Centrostephanus rodgersii } \\
\text { (Agassiz) }\end{array}$ & 57 & 4 \\
\hline $\begin{array}{l}\text { Heliocidaris tuberculata } \\
\text { (Lamarck) }\end{array}$ & 51 & 4 \\
\hline $\begin{array}{l}\text { Phyllacanthus parvispinus } \\
\text { (Tenison-Woods) }\end{array}$ & 1 & 1 \\
\hline Tripneustes gratilla (L.) & 45 & 3 \\
\hline \multicolumn{3}{|l|}{ Asteroidea } \\
\hline Acanthaster planci (L.) & 1 & 1 \\
\hline Astrostole rodolphi (Perrier) & 15 & 4 \\
\hline $\begin{array}{l}\text { Ophidiaster kermadecensis } \\
\text { Benham }\end{array}$ & 14 & 4 \\
\hline Pectria imperialis (Farquahar) & 5 & 3 \\
\hline
\end{tabular}


Table 2. Fish species counted in benthic transects at the Kermadecs, trophic category, total no. of individuals counted, and no. of sites (out of 6) at which they were counted. C: carnivore; $\mathrm{H}$ : herbivore; O: omnivore; P: planktivore. Trophic categories derived from Doak (1972), Russell (1983) and Francis (1988)

\begin{tabular}{|c|c|c|c|}
\hline Species & $\begin{array}{l}\text { Trophic } \\
\text { category }\end{array}$ & $\begin{array}{l}\text { Total no. } \\
\text { counted }\end{array}$ & $\begin{array}{l}\text { No. of } \\
\text { sites }\end{array}$ \\
\hline Acanthistius cinctus (Gunther) & $\mathrm{C}$ & 8 & 5 \\
\hline Amphichaetodon howensis (Waite) & $\mathrm{C}$ & 14 & 4 \\
\hline Anampses elegans Ogilby & $\mathrm{C}$ & 3 & 1 \\
\hline Aplodactylus etheridgii (Ogilby) & $\mathrm{H}$ & 64 & 6 \\
\hline Aulacocephalus temmincki Bleeker & $\mathrm{C}$ & 13 & 6 \\
\hline Bodianus vulpinus (Richardson) & $\mathrm{C}$ & 2 & 1 \\
\hline Canthigaster callisterna (Ogilby) & $\mathrm{C}$ & 6 & 3 \\
\hline Cheilodactylus ephippium McCulloch \& Waite & $\mathrm{C}$ & 46 & 6 \\
\hline Chrysiptera rapanui (Greenfield \& Hensley) & $P$ & 966 & 6 \\
\hline Cirrhitus splendens (Ogilby) & $\mathrm{C}$ & 39 & 5 \\
\hline Coris picta (Bloch \& Schneider) & $\mathrm{C}$ & 4 & 2 \\
\hline Coris sandageri Phillipps & $\mathrm{C}$ & 19 & 4 \\
\hline Ellerkeldia sp. & $\mathrm{C}$ & 3 & 2 \\
\hline Enchelycore ramosa (Griffin) & $\mathrm{C}$ & 1 & 1 \\
\hline Epinephelus damelii (Gunther) & $\mathrm{C}$ & 2 & 2 \\
\hline Girella cyanea Macleay & 0 & 8 & 3 \\
\hline Girella fimbriatus (McCulloch) & $\mathrm{H}$ & 5 & 2 \\
\hline Gymnothorax nubilis (Richardson) & $\mathrm{C}$ & 5 & 3 \\
\hline Kyphosus bigibbus (Lacepede) & $\mathrm{H}$ & 19 & 5 \\
\hline Notolabrus inscriptus (Richardson) & $\mathrm{C}$ & 30 & 6 \\
\hline Ostracion cubicus Linnaeus & $\mathrm{C}$ & 1 & 1 \\
\hline Parma alboscapularis Allen \& Hoese & $\mathrm{H}$ & 10 & 4 \\
\hline Parma kermadecensis Allen & $\mathrm{H}$ & 106 & 6 \\
\hline Parupeneus spilurus (Bleeker) & $\mathrm{C}$ & 39 & 3 \\
\hline Plagiotremus tapeinosoma (Bleeker) & $\mathrm{C}$ & 33 & 6 \\
\hline Pseudolabrus luculentus (Richardson) & $\mathrm{C}$ & 460 & 6 \\
\hline Pterois volitans (Linnaeus) & $\mathrm{C}$ & 2 & 2 \\
\hline Scorpaena cookii Gunther & $\mathrm{C}$ & 6 & 4 \\
\hline Stegastes fasciolatus (Ogilby) & $\mathrm{H}$ & 54 & 5 \\
\hline Suezichthys arquatus Russell & $\mathrm{C}$ & 4 & 2 \\
\hline Thamnaconus analis Waite & $\mathrm{C}$ & 5 & 3 \\
\hline Thalassoma ?amblycephalum (Bleeker) & $\mathrm{C}$ & 5 & 2 \\
\hline Trachypoma macracanthus Gunther & $\mathrm{C}$ & 10 & 5 \\
\hline Upeneichthys lineatus (Bloch \& Schneider) & $\mathrm{C}$ & 1 & 1 \\
\hline Zanclus cornutus Linnaeus & $\mathrm{C}$ & 2 & 1 \\
\hline
\end{tabular}

Table 3. Fish species counted in pelagic transects at the Kermadec Islands, total no. counted in transects, and no. of sites (out of 4 ) at which they were encountered

\begin{tabular}{|lcc|}
\hline Species & $\begin{array}{c}\text { Total no. } \\
\text { counted }\end{array}$ & $\begin{array}{c}\text { No. of } \\
\text { sites }\end{array}$ \\
\hline $\begin{array}{l}\text { Bathystethus cultratus } \\
\quad \text { Bloch \& Schneider) }\end{array}$ & 1570 & 4 \\
Labracoglossa nitida & 242 & 2 \\
$\quad$ McCulloch \& Waite & 4 & 1 \\
Pseudocaranx dentex & & \\
$\quad$ (Bloch \& Schneider) & 6 & 3 \\
Seriola lalandi Valenciennes & 82 & 2 \\
Atypichthys latus & & \\
$\quad$ McCulloch \& Waite & 63 & 3 \\
$\begin{array}{l}\text { Girella Cyanea Macleay } \\
\text { Scorpis violaceus (Hutton) }\end{array}$ & 244 & 2 \\
Kyphosus bigibbus (Lacepede) & 118 & 4 \\
Chromis dispilus Griffin & 1045 & 4 \\
\hline
\end{tabular}

water transects (Table 3). Of the benthic fishes, $12.9 \%$ of the individuals, and $17 \%$ of the species (Table 2) were classified as herbivores. In general, the most abundant species were widespread throughout the group of islands, while rare species usually only occurred at a single site (Tables 1 to 3 ).

\section{Benthic invertebrates at the Kermadecs}

Eight species were found at 3 or more sites (Table 1), but only 6 of these were considered common enough to investigate depth-related patterns. Of the other species, the slate pencil urchin Phyllacanthus parvispinus and the crown-of-thorns starfish Acanthaster planci occurred as single individuals, while 2 other starfish (Ophidiaster kermadecensis and Pectria imperialis) were widely scattered with respect to depth and site. A fifth uncommon invertebrate, Echinometra 
mathaei, was occasionally observed, but was never sampled in quadrats.

The limpet Patella kermadecensis was only present at the $3 \mathrm{~m}$ depth stratum (Fig. 2a). It occurred at densities up to $41 \mathrm{~m}^{-2}$, but was completely absent from our samples at L'Esperance Rock (Table 4). The trochid Tectus royanus occurred at all depths down to $18 \mathrm{~m}$. but was not abundant (Fig. 2b).

The echinoid Heliocidaris tuberculata was most abundant between depths of 3 and $12 \mathrm{~m}$ (Fig. 2c), but isolated individuals occurred at greater depths at L'Esperance Rock (Table 4). Its greatest sampled density was $7 \mathrm{~m}^{-2}$. The diadematid urchin Centrostephanus rodgersii was generally most abundant at a depth of $15 \mathrm{~m}$ (Fig. 2d), but was not found deeper than $9 \mathrm{~m}$ at Meyer Island (Table $4)$. The highest density of this species recorded was $6 \mathrm{~m}^{-2}$. C. rodgersii was absent from the $3 \mathrm{~m}$ depth stratum at all sites. Tripneustes gratilla occurred at all depths, but densities were highly variable (Fig. 2e). It was particularly abundant at L'Esperance Rock at 18 and $21 \mathrm{~m}$ (Table 4), which gave rise to an apparent overall pattern of increased density with depth (Fig. 2e). (a) Patella kermadecensis
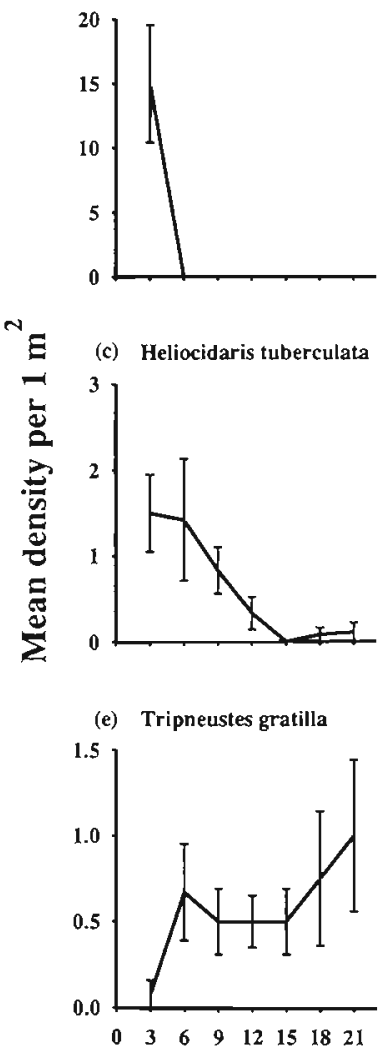

Depth (m) (e) Tripneustes gratilla (b) Tectus royanus

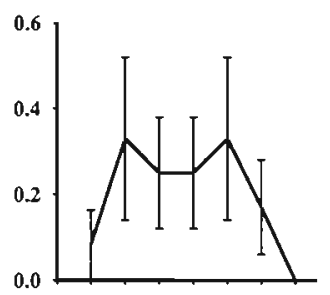

(d) Centrostephanus rodgersii
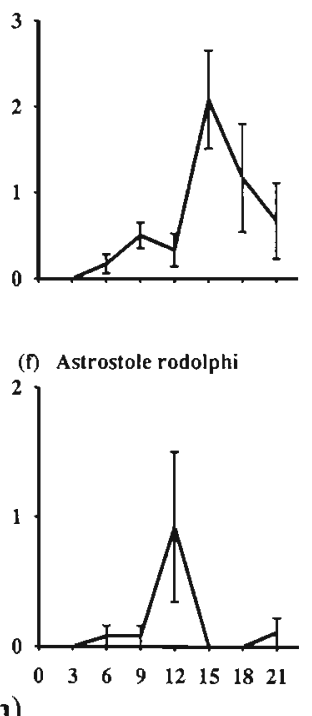

Fig. 2. Mean densities ( $\pm \mathrm{SE}$ ) of the 6 most abundant macroinvertebrates down a depth gradient. $\mathrm{n}=12$ for each depth except $21 \mathrm{~m}$ where $\mathrm{n}=9$
The asteroids Astrostole rodolphi, Ophidiaster kermadecensis, and Pectria imperialis were present in low numbers (Table 1). A. rodolphi was the only species to show any suggestion of a depth-related pattern, being abundant at a depth of $12 \mathrm{~m}$ (Fig. 2f). This pattern, however, only occurred at the Cheeseman Island site (Table 4).

\section{Benthic fish at the Kermadecs}

Acanthistius cinctus showed little variation in abundance with depth (Fig. 3a). Aulacocephalus temmincki was clearly most abundant in deep transects (Fig. 3b). Trachypoma macracanthus was most abundant in shallow transects, and its abundance decreased with increasing depth (Fig. 3c). The most abundant fish was Chrysiptera rapanui (Table 2). Its density was greatest in the deep (>18 m) stratum (Fig. 3d), and its abundance clearly increased with depth. The endemic pomacentrid Parma kermadecensis showed little variation in abundance with depth (Fig. 3e), while the abundance of Stegastes fasciolatus clearly decreased with increasing depth (Fig. 3f). The density of Cirrhitus splendens varied little with depth (Fig. 3g), but Aplodactylus etheridgii was more abundant in shallow transects (Fig. 3h). Cheilodactylus ephippium was more abundant in the upper 2 strata than in the deep one (Fig. 3i). The abundances of both Notolabrus inscriptus and Pseudolabrus luculentus (the second most abundant fish counted) did not change with depth (Fig. 3j to k). Plagiotremus tapeinosoma had low abundances in shallow transects but densities were similar in mid and deep strata (Fig. 31)

Parma kermadecensis, Aplodactylus etheridgii, and Pseudolabrus luculentus were present at all sites in shallow transects, only $P$. luculentus was present at all sites in mid transects, and both Chrysiptera rapanui and $P$. Iuculentus were present at all sites in deep transects (Table 5).

\section{Pelagic fish at the Kermadecs}

Greatest abundances of Bathystethus cultratus, Labracoglossa nitida and Kyphosus bigibbus occurred in shallow transects (Fig. 4a to c). Densities of Girella cyanea varied little with depth (Fig. 4d), while Chromis dispilus was abundant in mid and deep transects but very rare in shallow transects (Fig. 4e). B. cultratus was present at all sites in shallow transects, $G$. cyanea and $C$. dispilus were present at all sites in mid transects, and $C$. dispilus was present at all sites in deep transects (Table 6).

\section{Benthic invertebrates at Norfolk Island}

The only obvious species of benthic invertebrates at the 2 sites on Norfolk were echinoids (Table 7), all 5 of 
Table 4. Mean (standard error) densities of benthic invertebrates counted in quadrats at each depth and site

\begin{tabular}{|c|c|c|c|c|c|c|c|c|}
\hline Species & L'Esperance & Cheeseman & Chanter & Meyer & L'Esperance & Cheeseman & Chanter & Meyer \\
\hline & \multicolumn{4}{|c|}{$3 \mathrm{~m}$} & \multicolumn{4}{|c|}{$6 \mathrm{~m}$} \\
\hline Patella kermadecensis & $0.0(0.0)$ & $33.3(3.4)$ & $5.7(2.2)$ & $21.0(10.1\}$ & $0.0(0.0)$ & $0.0(0.0)$ & $0.0(0.0)$ & $0.0(0.0)$ \\
\hline Tectus royanus & $0.0(0.0)$ & $0.0(0.0)$ & $0.0(0.0)$ & $0.3(0.3)$ & $0.0(0.0)$ & $0.0(0.0)$ & $0.0(0.0)$ & $1.3(0.3)$ \\
\hline Heliocidaris tuberculata & $0.0(0.0)$ & $1.3(0.3)$ & $3.3(1.2)$ & $1.3(0.3)$ & $0.0(0.0)$ & $0.0(0.0)$ & $5.0(1.5)$ & $0.7(0.3)$ \\
\hline Centrostephanus rodgersij & $j \quad 0.0(0.0)$ & $0.0(0.0)$ & $0.0(0.0)$ & $0.0(0.0)$ & $0.0(0.0)$ & $0.0(0.0)$ & $0.3(0.3)$ & $0.3(0.3)$ \\
\hline Tripneustes gratilla & $0.0(0.0)$ & $0.0(0.0)$ & $0.3(0.3)$ & $0.0(0.0)$ & $1.3(0.9)$ & $0.0(0.0)$ & $1.0(0.6)$ & $0.3(0.3)$ \\
\hline \multirow[t]{2}{*}{ Astrostole rodolphi } & $0.0(0.0)$ & $0.0(0.0)$ & $0.0(0.0)$ & $0.0(0.0)$ & $0.0(0.0)$ & $0.0(0.0)$ & $0.3(0.3)$ & $0.0(0.0)$ \\
\hline & \multicolumn{4}{|c|}{$9 \mathrm{~m}$} & \multicolumn{4}{|c|}{$12 \mathrm{~m}$} \\
\hline Patella kermadecensis & $0.0(0.0)$ & $0.0(0.0)$ & $0.0(0.0)$ & $0.0(0.0)$ & $0.0(0.0)$ & $0.0(0.0)$ & $0.0(0.0)$ & $0.0(0.0)$ \\
\hline Tectus royanus & $0.3(0.3)$ & $0.0(0.0)$ & $0.0(0.0)$ & $0.7(0.3)$ & $0.0(0.0)$ & $0.0(0.0)$ & $1.0(0.0)$ & $0.0(0.0)$ \\
\hline Heliocidaris tuberculata & $1.3(0.3)$ & $0.0(0.0)$ & $1.7(0.7)$ & $0.3(0.3)$ & $0.0(0.0)$ & $0.0(0.0)$ & $1.3(0.7)$ & $0.0(0.0)$ \\
\hline Centrostephanus rodgersii & i $0.7(0.3)$ & $0.0(0.0)$ & $0.7(0.3)$ & $0.7(0.3)$ & $0.0(0.0)$ & $0.0(0.0)$ & $1.3(0.3)$ & $0.0(0.0)$ \\
\hline Tripneustes gratilla & $1.0(0.6)$ & $0.0(0.0)$ & $0.3(0.3)$ & $0.7(0.3)$ & $0.7(0.3)$ & $0.0(0.0)$ & $0.7(0.3)$ & $0.7(0.3)$ \\
\hline \multirow[t]{2}{*}{ Astrostole rodolphi } & $0.0(0.0)$ & $0.0(0.0)$ & $0.0(0.0)$ & $0.3(0.3)$ & $0.3(0.3)$ & $3.3(1.9)$ & $0.0(0.0)$ & $0.0(0.0)$ \\
\hline & \multicolumn{4}{|c|}{$15 \mathrm{~m}$} & \multicolumn{4}{|c|}{$18 \mathrm{~m}$} \\
\hline Patella kermadecensis & $0.0(0.0)$ & $0.0(0.0)$ & $0.0(0.0)$ & $0.0\{0.0\}$ & $0.0(0.0)$ & $0.0(0.0)$ & $0.0(0.0)$ & $0.0(0.0)$ \\
\hline Tectus royanus & $0.0(0.0)$ & $0.0(0.0)$ & $1.3(0.3)$ & $0.0(0.0)$ & $0.0(0.0)$ & $0.0(0.0)$ & $0.7(0.3)$ & $0.0(0.0)$ \\
\hline Heliocidaris tuberculata & $0.0(0.0)$ & $0.0(0.0)$ & $0.0(0.0)$ & $0.0(0.0)$ & $0.3(0.3)$ & $0.0(0.0)$ & $0.0(0.0)$ & $0.0(0.0)$ \\
\hline Centrostephanus rodgersii & $1.0(0.6)$ & $4.3(0.9)$ & $3.0(0.6)$ & $0.0(0.0)$ & $0.0(0.0)$ & $4.7(0.7)$ & $0.0(0.0)$ & $0.0(0.0)$ \\
\hline Tripneustes gratilla & $0.7(0.7)$ & $0.0(0.0)$ & $1.0(0.0)$ & $0.3(0.3)$ & $2.7(0.9)$ & $0.0(0.0)$ & $0.0(0.0)$ & $0.3(0.3)$ \\
\hline \multirow[t]{2}{*}{ Astrostole rodolphi } & $0.0(0.0)$ & $0.0(0.0)$ & $0.0\{0,0\}$ & $0.0(0.0)$ & $0.0(0.0)$ & $0.0(0.0)$ & $0.0(0.0)$ & $0.0(0.0)$ \\
\hline & \multicolumn{4}{|c|}{$21 \mathrm{~m}$} & & & & \\
\hline Patella kermadecensis & $0.0(0.0)$ & $0.0(0.0)$ & - & $0.0(0.0)$ & & & & \\
\hline Tectus royanus & $0.0(0.0)$ & $0.0(0.0)$ & - & $0.0\{0.0\}$ & & & & \\
\hline Heliocidaris tuberculata & $0.3(0.3)$ & $0.0(0.0)$ & - & $0.0(0.0)$ & & & & \\
\hline Centrostephanus rodgersii & $0.0(0.0)$ & $2.0(1.0)$ & - & $0.0(0.0)$ & & & & \\
\hline Tripneustes gratilla & $2.3(0.9)$ & $0.0(0.0)$ & - & $0.7(0.3)$ & & & & \\
\hline Astrostole rodolphi & $0.3(0.3)$ & $0.0(0.0)$ & - & $0.0(0.0)$ & & & & \\
\hline
\end{tabular}

which had been encountered at the Kermadecs. There was little evidence of vertical stratification of the abundances of Heliocidaris tuberculata, Centrostephanus rodgersii, or Tripneustes gratilla at a site near Duncombe Bay, an exposed locality (Table 7). Densities at this site seldom reached $1 \mathrm{~m}^{-2}$. Within the lagoon at Kingston Bay, water depths reached a maximum of only $4 \mathrm{~m}$, so depth-stratified transects could not be sampled. Echinoid densities here were very low (Table 7). An additional species, Echinometra mathaei, featured in some quadrats, and a species of Diadema was also observed in the lagoon. Extensive exploratory investigations revealed that, like the Kermadecs, stands of fucalean and laminarian macroalgae are absent.

\section{DISCUSSION}

\section{Patterns of abundance with depth}

Our observations of subtidal patterns support the description given by Schiel et al. (1986) for Boat Cove,
Raoul Island. A generalised zonation pattern based on the benthic invertebrates present could be described. At the Kermadecs, Patella kermadecensis dominated substrata to $3 \mathrm{~m}$. Below this, there was frequently a zone dominated by Heliocidaris tuberculata extending to a depth of about $9 \mathrm{~m}$. Between 12 and $18 \mathrm{~m}$ another echinoid, Centrostephanus rodgersii, was dominant, and various other echinoderms were present in low numbers. Several echinoid species occur at Norfolk, but their densities are even lower than at the Kermadecs and there were no obvious depth-related patterns in their abundances.

The composition of the echinoid fauna described above is more consistent with the temperate situation than the tropical one (Choat \& Schiel 1982, Jones \& Andrew 1990). Both Heliocidaris tuberculata and Centrostephanus rodgersii occur in temperate Australasia (Jones \& Andrew 1990), but Diadema, a typical tropical echinoid (Birkeland 1989), was rare in our study. In coastal Australia $H$. tuberculata is inconspicuous, dwelling mainly in the immediate subtidal 


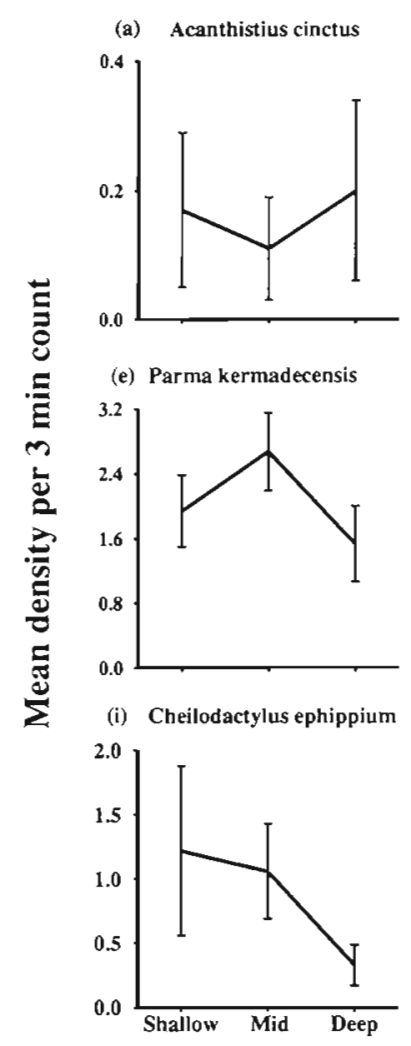

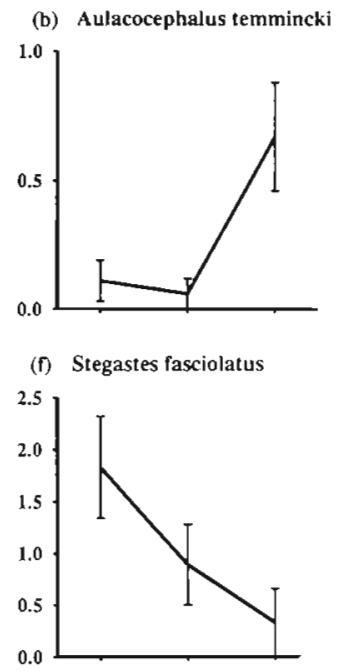

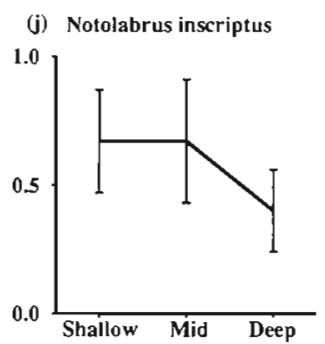

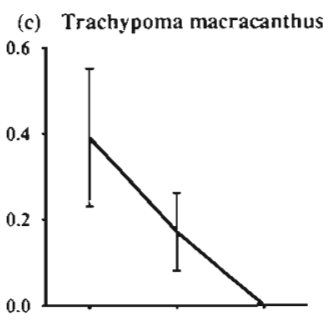

(g) Cirrhitus splendens

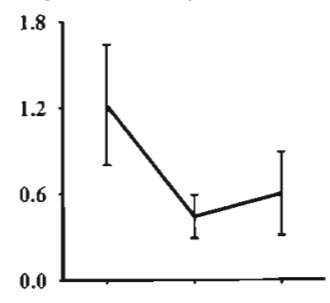

(k) Pseudolabrus luculentus

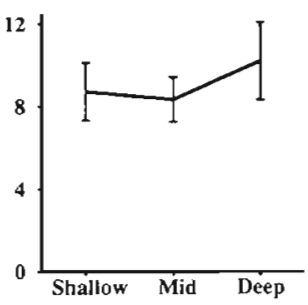

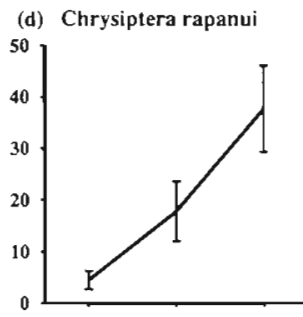

(h) Aplodactylus etheridgii

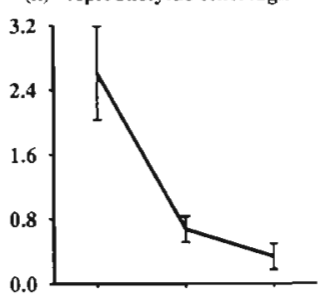

(1) Plagiotremus tapeinosoma

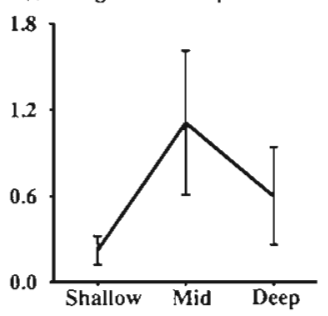

\section{Depth}

Fig. 3. Mean densities ( \pm SE) of the 12 most abundant benthic fishes sampled at 3 depth strata. $\mathrm{n}=18$ for each depth except in the deep stratum where $n=15$

(Jones \& Andrew 1990). However, it is abundant at Lord Howe Island (Dakin 1987) and at both island groups studied here. It is most abundant at depths less than $10 \mathrm{~m}$, an equivalent situation to that of Evechinus chloroticus (the major subtidal urchin in northern New Zealand) and $C$. rodgersii (the major subtidal urchin in southeastern Australia). Where $C$. rodgersii occurs in northern New Zealand, it is found at greater depths than E. chloroticus (Jones \& Andrew 1990). This same pattern was found at both the Kermadecs and Norfolk, with $C$. rodgersii occurring below the more dominant echinoid.

Densities of echinoids were sufficiently low in our study that a larger sample unit size would have been more appropriate for the description of depth-related patterns. We recommend that future echinoid surveys in subtropical areas use a $5 \mathrm{~m} \times 1 \mathrm{~m}$ tape transect, which is the standard unit currently being used in south-eastern Australia (Andrew \& Underwood 1989, Underwood et al. 1991).

Asteroids were very rare at both the Kermadecs and Norfolk, and they did not appear to be important in community organisation. The high density of Astrostole rodolphi at a depth of $12 \mathrm{~m}$ at Cheeseman Island suggests that this asteroid may be locally important, but more sampling is required to assess this. Menge (1982) suggested that predation by triggerfishes and puffers might control the abundances of asteroids in the tropics, but these groups were not conspicuous in our fish counts. Hypotheses based on poor dispersal to isolated islands could be given equal countenance. In rocky subtidal areas of northern New Zealand asteroids are generally not abundant (Choat \& Schiel 1982).

The vertical distributions of several fish species at the Kermadecs described by Schiel et al. (1986) are also verified: Kyphosus bigibbus, Stegastes fasciolatus, and Aplodactylus etheridgii occur in shallow areas, and Chrysiptera rapanui and Chromis dispilus occur in deeper water. Both Schiel et al. (1986) and Francis et al. (1987) identified Pseudolabrus luculentus as the most abundant labrid. The patterns of vertical distribution of the herbivorous fishes we observed are more similar to temperate waters than tropical ones; herbivores were generally most abundant in shallow transects, where the abundance of turfing algae was highest. The distribution of macroalgae may therefore control the vertical distribution of herbivores, rather than vice versa. Pomacentrids and aplodactylids were 
Table 5. Mean (standard error) densities of fish counted in benthic transects at each depth and site

\begin{tabular}{|c|c|c|c|c|c|c|}
\hline Species & L'Esperance & Cheeseman & Chanter & Dayrell & Meyer & Nugent \\
\hline & \multicolumn{6}{|c|}{ Shallow } \\
\hline Acanthistius cinctus & $0.0(0.0)$ & $0.7(0.7)$ & $0.0(0.0)$ & $0.0(0.0)$ & $0.3(0.3)$ & $0.0(0.0)$ \\
\hline Aulacocephalus temmincki & $0.0(0.0)$ & $0.0(0.0)$ & $0.3(0.3)$ & $0.0(0.0)$ & $0.3(0.3)$ & $0.0(0.0)$ \\
\hline Trachypoma macracanthus & $0.0(0.0)$ & $0.3(0.3)$ & $0.3(0.3)$ & $0.3(0.3)$ & $1.3(0.7)$ & $0.0(0.0)$ \\
\hline Chrysiptera rapanui & $0.0(0.0)$ & $0.0(0.0)$ & $14.0(7.8)$ & $1.3(1.3)$ & $10.3(2.4)$ & $1.3(1.3)$ \\
\hline Parma kermadecensis & $0.3(0.3)$ & $4.7(0.9)$ & $2.3(0.9)$ & $1.7(0.9)$ & $0.3(0.3)$ & $2.3(0.9)$ \\
\hline Stegastes fasciolatus & $0.3(0.3)$ & $0.0(0.0)$ & $1.3(1.3)$ & $4.3(0.3)$ & $1.0(0.0)$ & $4.0(1.2)$ \\
\hline Aplodactylus etheridgii & $4.0(0.0)$ & $1.3(1.3)$ & $1.0(1.0)$ & $1.0(0.6)$ & $1.7(0.3)$ & $6.7(0.9)$ \\
\hline Cirrhitus splendens & $0.0(0.0)$ & $1.3(0.9)$ & $0.3(0.3)$ & $2.7(1.7)$ & $0.3(0.3)$ & $2.7(1.2)$ \\
\hline Cheilodactylus ephippium & $0.3(0.3)$ & $1.0(0.6)$ & $1.0(0.6)$ & $0.0(0.0)$ & $4.3(3.8)$ & $0.7(0.7)$ \\
\hline Notolabrus inscriptus & $1.0(0.0)$ & $0.3(0.3)$ & $0.3(0.3)$ & $2.0(0.6)$ & $0.3(0.3)$ & $0.0(0.0)$ \\
\hline Pseudolabrus luculentus & $4.0(1.5)$ & $12.7(3.2)$ & $7.3(4.3)$ & $11.3(3.8)$ & $12.0(1.2)$ & $5.0(4.0)$ \\
\hline \multirow[t]{2}{*}{ Plagiotremus tapeinosoma } & $0.0(0.0)$ & $0.0(0.0)$ & $0.3(0.3)$ & $0.0(0.0)$ & $0.7(0.3)$ & $0.3(0.3)$ \\
\hline & \multicolumn{6}{|c|}{ Mid } \\
\hline Acanthistius cinctus & $0.0(0.0)$ & $0.0(0.0)$ & $0.3(0.3)$ & $0.0(0.0)$ & $0.0(0.0)$ & $0.3(0.3)$ \\
\hline Aulacocephalus temmincki & $0.0(0.0)$ & $0.0(0.0)$ & $0.3(0.3)$ & $0.0(0.0)$ & $0.0(0.0)$ & $0.0(0.0)$ \\
\hline Trachypoma macracanthus & $0.0(0.0)$ & $0.3(0.3)$ & $0.0(0.0)$ & $0.0(0.0)$ & $0.3(0.3)$ & $0.3(0.3)$ \\
\hline Chrysiptera rapanui & $0.0(0.0)$ & $4.3(3.8)$ & $30.0(18.5)$ & $44.7(20.3)$ & $22.0(11.9)$ & $5.7(1.5)$ \\
\hline Parma kermadecensis & $3.7(0.3)$ & $4.7(1.5)$ & $0.7(0.3)$ & $3.7(0.3)$ & $0.0(0.0)$ & $3.3(0.7)$ \\
\hline Stegastes fasciolatus & $0.3(0.3)$ & $0.0(0.0)$ & $4.3(0.3)$ & $0.3(0.3)$ & $0.0(0.0)$ & $0.3(0.3)$ \\
\hline Aplodactylus etheridgii & $1.0(0.0)$ & $0.7(0.7)$ & $1.0(0.0)$ & $0.0(0.0)$ & $1.0(0.6)$ & $0.3(0.3)$ \\
\hline Cirrhitus splendens & $0.0(0.0)$ & $0.3(0.3)$ & $0.3(0.3)$ & $0.7(0.3)$ & $0.0(0.0)$ & $1.3(0.3)$ \\
\hline Cheilodactylus ephippium & $2.0(0.6)$ & $3.0(1.5)$ & $0.0(0.0)$ & $0.3(0.3)$ & $0.0(0.0)$ & $1.0(0.6)$ \\
\hline Notolabrus inscriptus & $0.3(0.3)$ & $1.0(1.0)$ & $0.0(0.0)$ & $0.7(0.7)$ & $0.7(0.7)$ & $1.3(0.7)$ \\
\hline Pseudolabrus luculentus & $14.0(2.1)$ & $9.0(3.2)$ & $6.0(1.0)$ & $9.0(1.5)$ & $5.0(3.0)$ & $7.0(2.5)$ \\
\hline \multirow[t]{2}{*}{ Plagiotremus tapeinosoma } & $0.0(0.0)$ & $0.7(0.7)$ & $1.7(0.3)$ & $0.0(0.0)$ & $0.7(0.3)$ & $3.7(2.7)$ \\
\hline & \multicolumn{6}{|c|}{ Deep } \\
\hline Acanthistius cinctus & $0.0(0.0)$ & $0.0(0.0)$ & $0.0(0.0)$ & $0.3(0.3)$ & - & $0.7(0.7)$ \\
\hline Aulacocephalus temmincki & $0.3(0.3)$ & $1.3(0.9)$ & $0.3(0.3)$ & $1.0(0.0)$ & - & $0.3(0.3)$ \\
\hline Trachypoma macracanthus & $0.0(0.0)$ & $0.0(0.0)$ & $0.0(0.0)$ & $0.0(0.0)$ & - & $0.0(0.0)$ \\
\hline Chrysiptera rapanui & $2.3(2.3)$ & $39.3(20.3)$ & $66.0(25.6)$ & $34.3(6.1)$ & - & $46.3(16.6)$ \\
\hline Parma kermadecensis & $2.7(0.3)$ & $0.3(0.3)$ & $0.0(0.0)$ & $3.7(1.5)$ & - & $1.0(0.6)$ \\
\hline Stegastes fasciolatus & $0.0(0.0)$ & $0.0(0.0)$ & $1.7(1.7)$ & $0.0(0.0)$ & - & $0.0(0.0)$ \\
\hline Aplodactylus etheridgii & $0.7(0.7)$ & $0.0(0.0)$ & $0.7(0.3)$ & $0.3(0.3)$ & - & $0.0(0.0)$ \\
\hline Cirrhitus splendens & $0.0(0.0)$ & $0.0(0.0)$ & $0.0(0.0)$ & $0.3(0.3)$ & - & $2.7(0.3)$ \\
\hline Cheilodactylus ephippium & $0.0(0.0)$ & $0.7(0.7)$ & $0.7(0.3)$ & $0.0(0.0)$ & - & $0.3(0.3)$ \\
\hline Notolabrus inscriptus & $1.0(0.0)$ & $0.0(0.0)$ & $0.3(0.3)$ & $0.7(0.7)$ & - & $0.0(0.0)$ \\
\hline Pseudolabrus luculentus & $11.3(2.4)$ & $5.7(2.7)$ & $12.3(4.3)$ & $16.3(6.8)$ & - & $5.3(1.5)$ \\
\hline Plagiotremus tapeinosoma & $0.3(0.3)$ & $0.0(0.0)$ & $0.7(0.3)$ & $1.7(1.7)$ & - & $0.3(0.3)$ \\
\hline
\end{tabular}

present in low densities, but again were most abundant in shallow areas. Another herbivore, Parma kermadecensis, was most abundant at mid depths, however. A number of species of fish which occur both at the Kermadec Islands and in northern New Zealand display similar depth distributions in both areas. For example, Bathystethus cultratus appears to be exclusively found close to the surface (Francis 1988), while Acanthistius cinctus, Aulacocephalus temmincki, and Chromis dispilus are seldom found in shallow water (Doak 1972).

In northern New Zealand different biogenic habitat types are used by different feeding categories of fishes (Choat \& Ayling 1987). The patterns of vertical distrib- utions of fishes we found at the Kermadec Islands did not correspond well to feeding categories. For example, the serranids Acanthistius cinctus and Trachypoma macracanthus displayed opposite trends in abundance with depth at the Kermadec Islands, but are both thought to be carnivores on small fish and invertebrates (Doak 1972). As discussed for echinoids, the depth ranges of certain species may obviously be set by settlement patterns. In northern New Zealand, Notolabrus celidotus recruits at high densities into algal stands only in shallow water (Jones 1984). Pseudolabrus luculentus, the most abundant labrid at the Kermadec Islands, is of a similar morphology, size, and feeding habit to $N$. celidotus, but was uniformly 


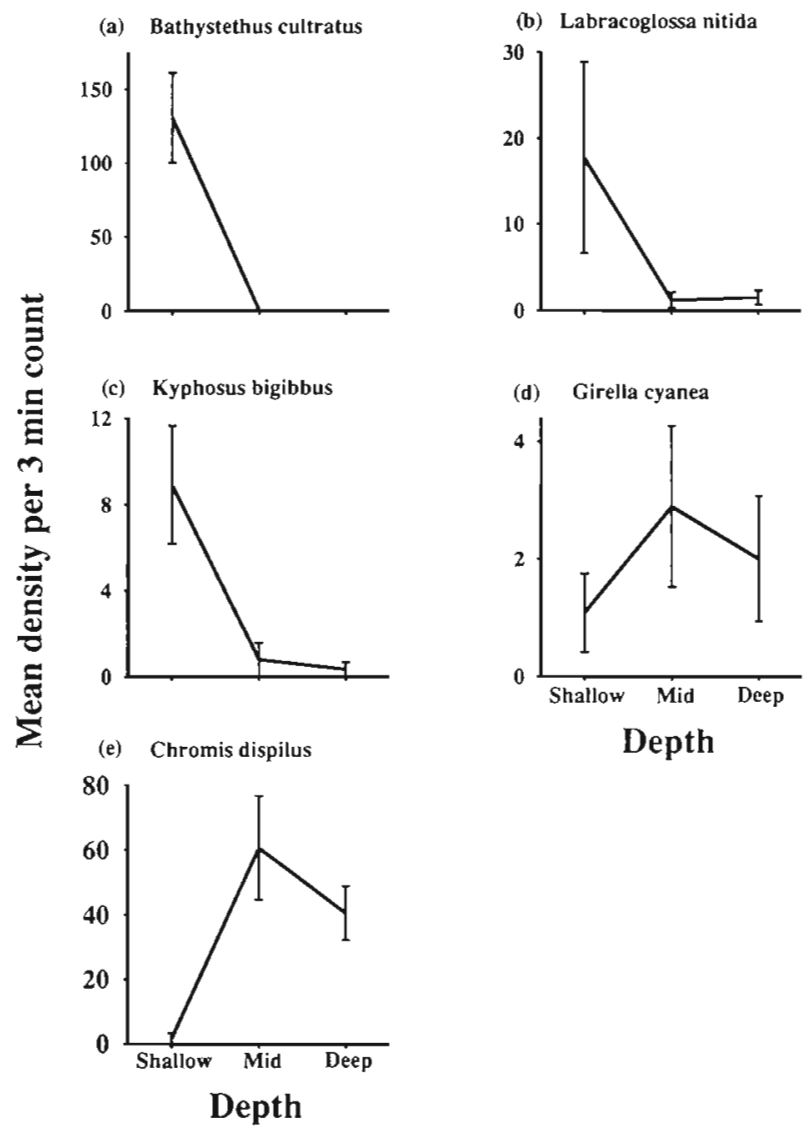

Fig. 4. Mean densities ( \pm SE) of the 5 most abundant pelagic fishes sampled at 3 depth strata. $\mathrm{n}=12$ for each depth except at mid depths where $n=9$ abundant across depth strata. One possible explanation for this difference is that the biogenic structure imposed by stands of macroalgae is linked to a shelter requirement, which the smaller algae at the Kermadecs do not provide.

\section{Macroalgal abundances and herbivory}

Despite numerous dives (in addition to quantitative surveys), we did not observe any stands of laminarian or fucalean macroalgae, and in this respect the Kermadecs and Norfolk Island resemble tropical systems. Species of Sargassum frequently dominate shallow macroalgal communities on high latitude coral reefs (Coles 1988). Records of Sargassum from the Kermadec Islands (Oliver 1915, Morton \& Miller 1968, Nelson \& Adams 1984) suggest that this brown alga may be limited to intertidal regions, although one sighting of a small subtidal stand has been made (M. P. Francis pers. comm.). As our sampling was not directed at intertidal areas, specimens could have been missed, although subsequent intertidal surveys have failed to find it (T. Anderson pers. comm.). In northern New Zealand $S$. sinclairii exhibits seasonal patterns of growth and abundance (Schiel 1985), which may also have affected our ability to quantitatively sample this species.

In tropical Oceania scarid and acanthurid fishes are considered to be more important herbivores on shallow reefs than echinoids (Birkeland 1989). Both

Table 6. Mean (standard error) abundances of fish in pelagic transects at 4 sites and 3 depths at the Kermadec Islands

\begin{tabular}{|c|c|c|c|c|}
\hline Species & L'Esperance & Cheeseman & Chanter & Dayrell \\
\hline & \multicolumn{4}{|c|}{ Shallow } \\
\hline Bathystethus cultratus & $166.7(83.3)$ & $50.0(50.0)$ & $216.7(33.3)$ & $90.0(37.9)$ \\
\hline Labracoglossa nitida & $0(0)$ & $O(0)$ & $66.7(33.3)$ & $4.3(3.0)$ \\
\hline Seriola lalandi & $0(0)$ & $0(0)$ & $0(0)$ & $0(0)$ \\
\hline Girella cyanea & $0.3(0.3)$ & $0(0)$ & $4.0(2.0)$ & $0(0)$ \\
\hline Kyphosus bigibbus & $11.0(6.1)$ & $0(0)$ & $16.7(6.7)$ & $3.0(1.0)$ \\
\hline \multirow[t]{2}{*}{ Chromis dispilus } & $0(0)$ & $0(0)$ & $0(0)$ & $6.7(6.7)$ \\
\hline & \multicolumn{4}{|c|}{ Mid } \\
\hline Bathystethus cultratus & $0(0)$ & $0(0)$ & $0(0)$ & - \\
\hline Labracoglossa nitida & $0(0)$ & $0(0)$ & $3.7(2.3)$ & - \\
\hline Seriola lalandi & $0.3(0.3)$ & $0.3(0.3)$ & $0(0)$ & - \\
\hline Girella cyanea & $5.0(2.9)$ & $0.7(0.7)$ & $3.0(3.0)$ & - \\
\hline Kyphosus bigibbus & $2.3(2.3)$ & $O(0)$ & $0(0)$ & - \\
\hline \multirow[t]{2}{*}{ Chromis dispilus } & $58.3(20.9)$ & $16.7(8.8)$ & $106.7(23.3)$ & - \\
\hline & \multicolumn{4}{|c|}{ Deep } \\
\hline Bathystethus cultratus & $0(0)$ & $O(0)$ & $0(0)$ & $O(0)$ \\
\hline Labracoglossa nitida & $0(0)$ & $0(0)$ & $2.7(2.7)$ & $3.3(1.8)$ \\
\hline Seriola lalandi & $0(0)$ & $1.0(0.6)$ & $0.3(0.3)$ & $O(0)$ \\
\hline Girella cyanea & $8.0(1.2)$ & $0(0)$ & $0(0)$ & $O(0)$ \\
\hline Kyphosus bigibbus & $1.3(1.3)$ & $0(0)$ & $0(0)$ & $O(0)$ \\
\hline Chromis dispilus & $28.3(6.0)$ & $30.0(10.0)$ & $43.3(12.0)$ & $60.0(30.6)$ \\
\hline
\end{tabular}


Table 7. Densities of echinoids at Norfolk Island. Mean density (SE) per $1 \mathrm{~m}^{2}(\mathrm{n}=8$ ) plotted against depth for a site near Duncombe Bay. Mean density (SE) per $50 \mathrm{~m}^{2}(n=18)$ on the reef slope in Kingston Bay Lagoon

\begin{tabular}{|c|c|c|c|c|c|c|}
\hline \multirow[t]{2}{*}{ Species } & \multicolumn{5}{|c|}{$\begin{array}{l}\text { Duncombe Bay } \\
\text { (ind } \mathrm{m}^{-2} \text { ) }\end{array}$} & \multirow{2}{*}{$\begin{array}{l}\text { Kingston Bay Lagoon } \\
\text { (ind. } 50 \mathrm{~m}^{-2} \text { ) } \\
\leq 4 \mathrm{~m}\end{array}$} \\
\hline & $3 \mathrm{~m}$ & $6 \mathrm{~m}$ & $9 \mathrm{~m}$ & $12 \mathrm{~m}$ & $15 \mathrm{~m}$ & \\
\hline Centrostephanus rodgersii & $0(0)$ & $0.4(0.2)$ & $0.6(0.4)$ & $0.4(0.3)$ & $0.1(0.1)$ & - \\
\hline Heliocidaris tuberculata & $1.3(0.5)$ & $0.3(0.2)$ & $0.8(0.4)$ & $0.3(0.3)$ & $0(0)$ & $0.7(0.2)$ \\
\hline Tripneustes gratilla & $0(0)$ & $0.1(0.1)$ & $0(0)$ & $0.1(0.1)$ & $0(0)$ & $1.3(0.3)$ \\
\hline Echinometra mathaei & - & - & - & - & - & $0.1(0.1)$ \\
\hline
\end{tabular}

Norfolk and the Kermadecs lack conspicuous macroalgae, but the herbivorous fish fauna is also limited. In our transects, $17.1 \%$ of species and $12.9 \%$ of the individuals counted were herbivorous. The minimum proportions reported from New Zealand and temperate Australia were $20.1 \%$ of species and $18.7 \%$ of individuals counted (Jones \& Andrew 1990). Both the number of herbivorous fish species and the number of individual herbivores in a sample varies so greatly on tropical reefs, however, that latitudinal comparisons are of limited value (Horn 1989, Parrish 1989). Much more information is required to assess patterns within biogeographic regions.

Neither this nor other studies of the Kermadec Islands have observed abundant scarid and acanthurid fishes. Francis et al. (1987) record Prionurus maculatus Ogilby as being rare at 2 of their sites, but absent from 3 others, and Francis (1991) records Acanthurus triostegus (Linnaeus) as occuring very rarely. No scarids have been recorded from the Kermadec Islands (Schiel et al. 1986, Francis et al. 1987, this study). Similarly, Prionurus maculatus is the only common acanthurid at Norfolk Island and Scarus rivulatus Valenciennes is the only parrotfish present there (M. P. Francis pers. comm.). It is probable that occasional scarids and acanthurids arrive at these islands as planktonic larvae but fail to establish populations.

Kyphosids were the most conspicuous element of the herbivorous fish fauna at the Kermadec Islands. The herbivorous habit of Kyphosus bigibbus must be questioned as it was frequently seen apparently feeding in surface schools. It was not closely associated with the substratum, and was most frequently counted in pelagic transects. Some kyphosids eat floating seaweeds in tropical and temperate waters (Horn 1989), but we did not record floating algae. Until gut contents are examined it is uncertain whether this species feeds during surface schooling, and if so, whether plant or animal material is ingested. In northern New Zealand, kyphosids and girellids usually browse on fucalean algae, but seldom remove plants (Jones \& Andrew 1990). Girella cyanea, which we saw in low numbers, is at least partly carnivorous (Doak 1972).
Echinoids and other grazing invertebrates are thought to control the distribution of algae in temperate waters, and distributions of fishes may in turn be controlled by algae (Choat \& Ayling 1987, but see Holbrook et al. 1990). Densities of benthic invertebrates are lower at the Kermadec Islands than in temperate New Zealand and their composition is different. Reefs in northern New Zealand have high abundances of a single echinoid (Evechinus chloroticus) and a diverse assemblage of herbivorous gastropods (Ayling 1981, Choat \& Schiel 1982). Similarly, the subtropical Houtman Abrolhos have high abundances of a number of species of gastropod, while Echinometra mathaei is the only common echinoid (Hatcher \& Rimmer 1985). This contrasts with the Kermadecs, where several species of echinoids occur at relatively low densities but subtidal gastropods are scarce (the relatively uncommon trochid Tectus royanus was the only gastropod encountered below $3 \mathrm{~m}$ ). Large grazing molluscs were not found at Norfolk Island, and they are known to be rare there (Paul 1980).

Schiel et al. (1986) suggested that the absence of macroalgae is more readily explained in terms of the lack of long-range dispersal of propagules than by constant removal by herbivores. All 4 species of the fucoid genus Carpophyllum commonly found in northern New Zealand have been recorded as drift specimens from Raoul Island and a live specimen of the laminarian Ecklonia radiata was dredged from near Macauley Island (Nelson \& Adams 1984). Such occasional specimens, however, may not be reproductively viable, sporelings may be unable to grow under the prevailing physical conditions, or herbivores may be able to completely remove them because of their low densities.

In temperate waters, areas devoid of macroalgae ('barrens') are frequently maintained by low densities of herbivores despite the proximity of sources of propagules (e.g. Fletcher 1987. Harrold \& Pearse 1987 , Andrew 1988). Young macroalgae may be particularly susceptible to grazing by invertebrates, and low densities of these herbivores may be able to maintain barrens by removing any colonisers. A similar situation may occur at the Kermadec Islands, where founder 
densities may be insufficient to permit the establishment of stands of macroalgae. It is also possible that inconspicuous herbivores may remove sporelings, but the abundances of microherbivores such as amphipods at the Kermadec Islands are unknown.

\section{Biogeographic trends in community organisation}

We feel that mobile benthic invertebrates and herbivorous fishes occur at subtropical, southwestern Pacific islands in insufficient densities, and their patterns of distribution are too patchy in space to completely exclude fucalean and laminarian macroalgae; most species of herbivore were absent from at least 1 sampling site. Measurements of grazing intensity and manipulative experiments involving exclusions or removals of grazers are planned to test this hypothesis. It must be remembered, however, that the results from such experiments (which are necessarily on a limited spatial and temporal scale) will never be able to address biogeographical questions; it is always possible to invoke herbivory in the past to account for the present absence of macroalgae. We merely note here the uncoupling of abundances of macroalgae and herbivores.

There are many possible explanations for the absence of particular groups of species from the Kermadecs and Norfolk Island. In addition to hypotheses based on a limited supply of propagules (Schiel et al. 1986), exposure to wave action may have an important effect on the species which are able to survive at these subtropical islands. We observed a number of labrids of the genera Anampses and Thalassoma only in the shelter of Boat Harbour on Meyer Island; these genera are also common in Boat Cove, a sheltered bay on Raoul Island (Francis et al. 1987). Chaetodontid fishes only survive in Kingston Lagoon at Norfolk Island (Francis et al. unpubl.) and shelter considerations may also limit the upper distribution of echinoids (Birkeland 1989). The Kermadec Islands have very few sheltered areas, and underwater topography is kept simple by the absence of any vertical relief provided by dense stands of tall algae (the temperate situation) or of any habitat complexity provided by finely divided coral heads (the tropical situation).

We suggest that the faunal composition and patterns of abundance of benthic invertebrates and fishes at the Kermadec Islands have a greater affinity to temperate Australasia than conventional herbivore-dominated tropical systems. We identify the further description of patterns of abundance of macroalgae, microherbivores, benthic invertebrates, and fishes in subtropical areas as a fruitful area of future research.
Acknowledgements. We thank W. Murray and R. Veitch from the New Zealand Department of Conservation for their assistance in organising and funding the expedition to the Kermadecs. We also thank the captain and crew of HMNZS 'Tui' for transport to and from the Kermadec Islands, and the 1988 Raoul Island Meteorological Station team for their hospitality and assistance. The Norfolk Island survey was partly funded by the Australian National Parks \& Wildlife Service, and supported by the South Pacific Centre for the Environment. We thank G. Hicks, M. Christian, G. Evans and G. Bennett for logistical support at Norfolk. M. Francis, C, Syms, G. Jones, and C. Battershill commented on early drafts, and T. Anderson assisted with the preparation of the figures

\section{LITERATURE CITED}

Allen, G. R., Hoese, D. F., Paxton, J. R., Randall, J. E., Russell, B. C., Starck, W. A., Talbot, F. H., Whitley, G. P. (1976). An annotated checklist of the fishes of Lord Howe Island. Rec. Aust. Mus. 30: 365-454

Andrew, N. L. (1988). Ecological aspects of the common sea urchin, Evechinus chloroticus, in northeastern New Zealand. N.Z. J. mar. Freshwat. Res. 22: 415-426

Andrew, N. L., Underwood, A. J. (1989). Patterns of abundance of the sea urchin Centrostephanus rodgersii (Agassiz) on the central coast of New South Wales, Australia. J. exp. mar. Biol. Ecol. 131: 61-80

Ayling, A. M. (1981). The role of biological disturbance in temperate subtidal encrusting communities. Ecology 62 : $830-847$

Birkeland, C. (1989). The influence of echinoderms on coralreef communities. In: Jangoux, M., Lawrence, J. M. (eds.) Echinoderm studies, Vol. 3. A. A. Balkema, Rotterdam, p. $1-79$

Choat, J. H. (1982). Fish feeding and the structure of benthic communities in temperate waters. Ann. Rev. Ecol. Syst. 13: 423-449

Choat, J. H., Ayling, A. M. (1987). The relationship between habitat structure and fish faunas on New Zealand reefs. J. exp. mar. Biol. Ecol. 110: 257-284

Choat, J. H., Ayling, A. M., Schiel, D. R. (1988). Temporal and spatial variation in an island fish fauna. J. exp. mar Biol. Ecol. 121: 91-111

Choat, J. H., Schiel, D. R. (1982). Patterns of distribution and abundance of large brown algae and invertebrate herbivores in subtidal regions of northern New Zealand. J. exp. mar. Biol. Ecol. 60: 129-162

Coles, S. L. 1988: Limitations on reef coral development in the Arabian Gulf: temperature or algal competition? In: Choat, J. H. et al. (eds.) Proc. 6th int. coral Reef Symp., Vol. 1. Sixth International Coral Reef Symposium Executive Committee, Townsville, p. 211-216

Crossland, C. J. 1988: Latitudinal comparisons of coral reef structure and function. In: Choat, J. H. et al. (eds.) Proc 6th int. coral Reef Symp., Vol. 1. Sixth International Coral Reef Symposium Executive Committee, Townsville, p. 221-226

Dakin, W. J. (1987). Australian seashores. Fully revised edn. Angus \& Robertson, North Ryde, New South Wales

Doak, W. (1972). Fishes of the New Zealand region. Hodder \& Stoughton, Auckland

Fletcher, W. J. (1987). Interactions among subtidal Australian sea urchins, gastropods, and algae: effects of experimental removals. Ecol. Monogr. 57: 89-109

Francis, M. P. (1988). Coastal fishes of New Zealand. Heinemann Reed, Auckland 
Francis, M. P. (1991). Additions to the fish faunas of Lord Howe, Norfolk, and Kermadec Islands, Southwest Pacific Ocean. Pacif. Sci. 45: 204-220

Francis, M. P., Grace, R. V., Paulin, C. D. (1987). Coastal fishes of the Kermadec Islands. N.Z. J. mar. Freshwat. Res. 21. $1-13$

Gaines, S. D., Lubchenco, J. (1982). A unified approach to marine plant-herbivore interactions. II. Biogeography. Ann. Rev. Ecol. Syst. 13: 111-138

Gordon, D. M. (1986). Marine communities of the Cape Peron, Shoalwater Bay and Warnbro Sound region, Western Australia. Bulletin 264. Department of Conservation and Environment, Marine Impacts Branch, Perth

Harrold, C., Pearse, J. S. (1987). The ecological role of echinoderms in kelp forests. In: Jangoux, M., Lawrence, J. M. (eds.) Echinoderm studies Vol. 2. A. A. Balkema, Rotterdam, p. 137-233

Hatcher, B. G., Rimmer, D. W. (1985). The role of grazing in controlling benthic community structure on a high latitude coral reef: measurements of grazing intensity. In: Gabrie, C. et al. (eds.) Proc. 5th int. coral Reef Congr., Vol. 6. Antenne Museum-EPHE, Moorea, French Polynesia, p. $229-236$

Hermes, N. (ed ) (1986). A revised annotated checklist for the vascular plants and vertebrate animals of Norfolk Island. Revised edition. Flora \& Fauna Society of Norfolk Island, Kingston

Holbrook, S. J., Schmitt, R. J., Ambrose, R. F. (1990). Biogenic habitat structure and characteristics of temperate reef assemblages. Aust. J. Ecol. 15: 489-503

Horn, M. H. (1989). Biology of marine herbivorous fishes Oceanogr. mar. Biol. A. Rev. 27: 167-272

Jones, G. P. (1984). Population ecology of the temperate reef fish Pseudolabrus celidotus Bloch \& Schneider (Pisces: Labridae). I. Factors affecting recruitment. J. exp. mar. Biol. Ecol. 75: 257-276

Jones, G. P., Andrew, N. L. (1990). Herbivory and patch dynamics on rocky reefs in temperate Australasia: the roles of fish and sea urchins. Aust. J. Ecol. 15: 505-520

Kingsford, M. J. (1989). Distribution patterns of planktivorous reef fish along the coast of northeastern New Zealand. Mar. Ecol. Prog. Ser. 54: 13-24

Knox, G. A. (1963). The biogeography and intertidal ecology of the Australasian coasts. Oceanogr. mar. Biol. A. Rev. 1: $341-404$

Lawrence, J. M. (1975). On the relationships between marine plants and sea urchins. Oceanogr. mar. Biol. A. Rev. 13: 213-286

McKnight, D. G. (1968). Some echinoderms from the Kermadec Islands. N.Z. J. mar. Freshwat. Res. 2: 505-526

Meekan, M. G. (1986). The distribution and abundance of the herbivorous fish Odax pullus and its influence on its food plant Ecklonia radiata, within a temperate reef environment. M.Sc. thesis, University of Auckland

This article was presented by J.S. Pearse, Santa Cruz, California, USA
Menge, B. A. (1982). Effects of feeding on the environment: Asteroidea. In: Jangoux, M., Lawrence, J. M. (eds.) Echinoderm nutrition. A. A. Balkema, Rotterdam, p $521-551$

Meteorological Office (1963). Meteorological glossary, 4th edn. H. M. S. O., London

Morton, J. E., Miller, M. M. (1968). The New Zealand seashore Collins, Auckland

Nelson, W. A., Adams, N. M. (1984). Marine algae of the Kermadec Islands. National Museum of New Zealand, Misc. Ser. No. 10

Oliver, W. R. B. (1910). The vegetation of the Kermadec Islands. Trans. N. Z. Inst. 42:118-175

Oliver, W. R. B. (1915). The mollusca of the Kermadec Islands. Trans. N. Z. Inst. 47: 509-568

Parrish, J. D. (1989). Fish communities of interacting shallowwater habitats in tropical oceanic regions. Mar. Ecol. Prog. Ser. 58: 143-160

Paul, W. J. (1980). Marine shells collected at Norfolk Island. Cookia 4: $12-15$

Russell, B. C. (1983). The food and feeding habits of rocky reef fish of north-eastern New Zealand. N.Z. J. mar. Freshwat. Res. 17: 121-145

Schiel, D. R. (1985). Growth, survival and reproduction of two species of marine algae at different densities in natural stands. J. Ecol. 73: 199-217

Schiel, D. R., Foster, M. S. (1986). The structure of subtidal algal stands in temperate waters. Oceanogr. mar. Biol. A Rev. 24: 265-307

Schiel, D. R., Kingsford, M. J., Choat, J. H. (1986). Depth distribution and abundance of benthic organisms and fishes at the subtropical Kermadec Islands. N.Z. J. mar. Freshwat. Res. 20: 521-535

Steneck, R. S. (1988). Herbivory on coral reefs: a synthesis. In: Choat, J. H. et al. (eds.) Proc. 6th int coral Reef Symp. Vol. 1. Sixth International Coral Reef Symposium Executive Committee, Townsville, p. 37-49

Underwood, A. J., Kingsford, M. J., Andrew, N. L. (1991). Patterns in shallow subtidal marine assemblages along the coast of New South Wales. Aust. J. Ecol. 6: 231-249

Veron, J. E. N., Howe, R. A., Done, T. J, Zell, L. D., Dodkin, M. J., O'Farrell, A. F. (1974). Corals of the Solitary Islands, central New South Wales. Aust. J. mar. Freshwat. Res. 25 $193-208$

Waite, E. R. (1910). A list of the known fishes of Kermadec and Norfolk Islands and a comparison with those of Lord Howe Island. Trans. N.Z. Inst. 42: 370-383

Waite, E. R. (1912). Additions to the fish fauna of the Kermadec Islands. Proc. N. Z. Inst 44: 28-29

Waite, E. R. (1916). A list of the fishes of Norfolk Island and indication of their range to Lord Howe Island, Kermadec Island, Australia, and New Zealand. Trans. Proc. R. Soc. South Aust. 40: $452-458$

Manuscript first received: April 2, 1991

Revised version accepted: April 14, 1992 